\title{
EFFECTS OF WALKING ON THE MOOD OF PHYSICALLY ACTIVE OLDER PEOPLE
}

\author{
EFEITOS DA CAMINHADA SOBRE OESTADO DE HUMORDE IDOSOS FISICAMENTEATIVOS
}

EFECTOS DELA CAMINATA SOBREEL ESTADO DE HUMOR DE ADULTOS DE LA TERCERA EDAD ACTIVOS

Original Article

ARTIGO ORIGINAL

Artículo Original

Amandio Aristides Rihan Geraldes (Physical Education Professional)

Willames Brito da Silva²

(Physical Education Professional)

Pedro Balikian Júnior ${ }^{3}$

(Physical Education Professional)

Piettra Moura Galvão Pereira ${ }^{4}$

(Physical Education Professional)

1. Universidade Federal de Alagoas (UFAL), Fitness, Performance and Health Laboratory, Maceió,

AL, Brazil.

2. Universidade Federal de Alagoas (UFAL), Physical Education Course, Maceió, AL, Brazil.

3. Universidade Federal de Alagoas (UFAL), Maceió, AL, Brazil.

4. Centro Universitário CESMAC

(CESMAC), Maceió, AL, Brazil.

\section{Correspondence:}

Prof. Dr. Amandio Aristides Rihan Geraldes. Fitness, Performance and Health Laboratory (LAFIDES). Campus AC Simões. Av. Lourival Melo Mota s/n. Tabuleiro dos Martins, AL, Brazil. 57072-970. amandioargeraldes@gmail.com.

\begin{abstract}
Introduction: Due to the relationship between exercise and mood (MO), physical activity is being widely used as a nonpharmacological strategy in the treatment of depression. However, most studies have used sample groups of subjects who, besides suffering from ill health, are also older and sedentary, thus presenting wider "windows of adaptations" when compared to apparently healthy or physically active individuals. Thus, the effects of exercise on MO in physically active elderly individuals are yet to be clarified. Objective: To verify the acute effects of 30 minutes of walking of mild to moderate intensity on the $\mathrm{MO}$ of physically active elderly subjects. Methods: A total of 43 volunteers ( $86 \%$ women and $14 \%$ men), who participated regularly in an activity program offered by a health care institution in Alagoas, were selected in a non-probabilistic manner. MO was evaluated using the Profile of Mood States (POMS) questionnaire before and after 30 minutes of walking. The comparison between means was verified with Student's t-test. Results: Relative differences were observed in all dimensions of MO, ranging from $16.4 \%$ (Vigor) to $56.3 \%$ (Rage). However, statistically significant differences were only found in the Vigor $(p=0.00)$ and Confusion ( $p=0.026)$ dimensions. Conclusion: It is concluded that a 30-minute walk, performed at mild to moderate intensity, as recommended by the main medical guidelines for obtaining general health benefits, may be an effective way of promoting $\mathrm{MO}$ improvements in physically active elderly people. The study confirms the fact that walking may potentially be an interesting nonpharmacological strategy for the treatment of depression. Level of Evidence ll; Therapeutic studies - Investigating treatment results.
\end{abstract}

Keywords: Mental health; Physical activity; Exercise; Aging.

\section{RESUMO}

Introdução: Devido às relações entre os exercícios físicos e o estado de humor (EH), tais atividades estão sendo amplamente utilizadas como estratégias não medicamentosas no tratamento da depressão. Entretanto, a maioria dos estudos tem utilizado amostras de indivíduos que, além de doentes, são mais velhos e sedentários, portanto, apresentam "janelas de adaptações" mais amplas, quando comparados àqueles aparentemente saudáveis ou fisicamente ativos. Sendo assim, os efeitos dos exercícios sobre o EH em idosos fisicamente ativos ainda devem ser esclarecidos. Objetivo: Verificar os efeitos agudos de 30 minutos de caminhada, com intensidade entre leve e moderada, sobre o EH de idosos fisicamente ativos. Métodos: Foram selecionados, de maneira não probabilística, 43 voluntários (86\% mulheres e 14\% homens), participantes habituais de um programa de atividades oferecido por uma instituição de saúde de Alagoas. Avaliou-se o EH com o Profile of Mood States (POMS) antes e após 30 minutos da caminhada. A comparação entre as médias foi verificada com o teste t de Student. Resultados: Foram observadas diferenças relativas em todas as dimensões do EH, variando entre 16,4\% (vigor) e 56,3\% (raiva). Entretanto, somente nas dimensões vigor $(p=0,00)$ e confusão $(p=0,026)$ verificaram-se diferenças estatisticamente significativas. Conclusão: Conclui-se que com 30 minutos de caminhada, realizada com intensidade leve a moderada, conforme recomendado pelas principais diretrizes médicas para a obtenção de benefícios para a saúde geral, pode-se ter uma forma efetiva de promover meIhorias no EH de idosos fisicamente ativos. Confirma-se a possibilidade de a caminhada ser uma interessante estratégia não medicamentosa para o tratamento da depressão. Nível de evidência l; Estudos terapêuticos - Investigação dos resultados do tratamento.

Descritores: Saúde mental; Atividade física; Exercício; Envelhecimento.

\section{RESUMEN}

Introducción: Debido a las relaciones entre los ejercicios físicos y el estado de humor (EH), tales actividades están siendo ampliamente utilizadas como estrategias no medicamentosas en el tratamiento de la depresión. Entretanto, la mayoría de los estudios ha utilizado muestras de individuos que, además de enfermos, poseen más edad y son sedentarios, por lo tanto, presentando "ventanas de adaptaciones" más amplias, en comparación con aquellos aparentemente saludables o físicamente activos. Siendo así, los efectos de los ejercicios sobre el EH en adultos mayores físicamente activos todavía deben ser esclarecidos. Objetivo: Verificar los efectos agudos de 30 minutos de caminata con intensidad entrelevey moderada, sobre el EH de adultos mayores físicamente activos. Métodos: Fueron seleccionados, de manera no probabilistica, 43 voluntarios (86\% mujeres y $14 \%$ hombres), participantes habituales de un programa 
de actividades, ofrecido por una institución de salud de Alagoas. Se evaluó el EH con el Profile of Mood States (POMS) antes y después de 30 minutos caminata. La comparación entre los promedios se verificó con el test t de Student. Resultados: Se observaron diferencias relativas en todas las dimensiones del EH, variando entre 16,4\% (Vigor) y 56,3\% (Ira). Entretanto, sólo en las dimensiones vigor $(p=0,00)$ y confusión $(p=0,026)$ se verificaron diferencias estadísticamente significativas. Conclusión: Se concluye que con 30 minutos de caminata, realizada con intensidad leve a moderada, de acuerdo a lo recomendado por las principales directrices médicas para la obtención de beneficios para la salud general, puede tenerse una forma efectiva de promover mejoras en el EH de adultos mayores físicamente activos. Se confirma la posibilidad de que la caminata sea una interesante estrategia no medicamentosa para el tratamiento de la depresión. Nivel de evidencia Il; Estudios terapéuticos - Investigación de los resultados del tratamiento.

Descriptores: Salud mental; Actividad física; Ejercicio; Envejecimiento.

\section{INTRODUCTION}

In order to minimize morphophysiological changes related to aging, functional limitations, severity of diseases and, in particular, to prevent the onset of new diseases, the American College of Sports Medicine (ACSM) and the American Heart Association (AHA) recommend the regular practice of physical activities. ${ }^{1}$ Thus, physical activities such as dances, Tai Chi Chuan, resistance training and walking/running, among others, have been increasingly used in interventions aimed at maintaining or improving levels of physical/functional fitness, health and quality of life (QOL) in elderly adults. ${ }^{2-8}$

The evidence is growing, demonstrating important correlations between regular practice of PA and mental health. Mangialasche et al., ${ }^{9}$ and Bridle et al., ${ }^{10}$ for example, demonstrated associations between the practice of PA, especially those structured, such as sports and exercises, ${ }^{11}$ with the sense of well-being, mood and general health. In addition to confirming the importance of regular physical exercise (PE) for the cognitive, emotional and motor domains, these studies, demonstrate the importance of PE as a non-medical resource for the prevention and treatment of mental illness, ${ }^{10}$ especially in anxiety and depression. ${ }^{1}$

Mental illness rates are increasing in all countries, affecting people of both sexes and of all ages, ${ }^{12}$ however, such rates are more important and notable in developing countries, and in particular, for female subjects, elderly and or institutionalized people, ${ }^{13,14}$ making these populations more susceptible to fragility, vulnerability and morbidity and mortality. ${ }^{9}$

Due to associations between levels of PE, mood state (MS), anxiety, vigor, anger and decreased disposition to life, depression appears to be the most sensitive mental illness to PE interventions. ${ }^{11,14}$

Depression is a disease characterized by episodes of depressed mood, loss of interest and pleasure for almost all activities, changes in appetite, weight, sleep, decreased energy and feelings of loss or guilt.13 Thus, in addition to personal injury, the disease has a relevant role for society, being one of the main responsible for increased absenteeism at work, low productivity, functional limitations, hospitalizations and suicidal ideation. ${ }^{12}$

In Brazil, it is estimated that $17 \%$ of the general population suffers from depression. Among the elderly, rates range from 10 to $30 \% 13$. However, the prevalence rates of the disease are likely to be higher, since more than $50 \%$ of the cases are undiagnosed ${ }^{15,16}$.

Several studies have shown that the regular practice of PE is able to positively influence self-esteem and self-confidence, favoring well-being and MS, thus contributing to a decrease in the severity and frequency of depressive episodes. . $^{13,17,18,19}$

Although the anxiolytic effects of exercise have not yet been fully clarified, research on animal models has shown that the possible mechanisms of PE on depression are related to increased production of neuromodulators, such as serotonin and norepinephrine, which interfere in the reactivity to stress, promoting results similar to those caused by the use of drugs used by pharmacotherapy. ${ }^{20}$ In addition, the potential of psychological mechanisms related to the regular practice of PE, such as learning, changes in body schema, adoption of healthy attitudes and / or behaviors, social reinforcement and leisure, should not be overlooked. ${ }^{21}$

Besides the costs, the fact that the pharmacological resources used for the treatment of mental illnesses present important side effects, ${ }^{20}$ the use of PE as a non-pharmacological resource for the maintenance or improvement of MS has been increasing. Therefore, this study aimed to verify the effects of a 30-minute walking session, performed with moderate intensity, as recommended by the main medical guidelines, about the MS of apparently healthy and physically active elderly, habitual participants in a program of physical exercise activities and other leisure activities, offered by a public health institution of a municipality in the interior of the state of Alagoas.

\section{MATERIALS AND METHODS}

\section{Population and Sample}

To participate in this experimental study, 43 volunteers (37 women and six men) over 60 years old who were enrolled in a walking and others leisure activities program offered by the Núcleo de Apoio à Família (NASF) of the Health Department of an Alagoano municipality, were selected in a non-probabilistic manner.

The aforementioned bi-weekly program consisted of outdoor walking and participation and discussions about the benefits of regular physical activity and the adoption of healthy nutritional habits for the maintenance or improvement of health and QOL.

To participate in the study, the voluntary should have 60 or more years of age, be physically active, accumulating 150 minutes weekly of aerobic physical activities (assessed as recommended by Nelson et al., be able to understand the explanations and answer the questions raised by the study, as well as not to report anxiety disorders, depression and/or other mental illnesses.

After the contact and approval of the study by the heads of the Health Department, the first of three meetings with the group was scheduled. During that meeting, the objectives, possible risks and benefits related to the research were explained, and all the volunteers interested in participating in the study answered a general questionnaire for the collection of socio-demographic data (age, ethnicity, marital status, physical activity levels and health status, among others) and evaluation of the inclusion criteria, besides being familiar with the evaluation of the mood scale.

At the second meeting, 24 hours later, familiarization and anchoring procedures were performed using the Borg Scale to ensure the 
maintenance of the intensity of the walk. Finally, in the last meeting, the intervention itself was carried out.

All stages of the study were approved by the research ethics committee of the Federal University of Alagoas, in accordance with Resolution 466/12 of the National Health Council (number: 023229/201-24) and all The volunteers signed the Term of Free and Informed Consent.

\section{Procedures and methods}

\section{Demographic Data Collection and Evaluation of Levels of Physical Activities}

The questionnaire, used for the collection of sociodemographic and the evaluation of physical activity levels, was applied in the form of individual interviews conducted by the researchers.

\section{Mood Assessment Profile Mood State (POMS)}

The POMS was used for the evaluation of MS. In addition to being extensively used for the evaluation of $\mathrm{MS}^{23}$ the choice of such an instrument was due to its simplicity, sensitivity in detecting the changes in MS, and mainly because it was validated in Portuguese by Rohlfs. ${ }^{24}$ The 24 questions contained in the questionnaire are intended to evaluate six dimensions of MS: Tension (feelings of anxiety, muscle tension, restlessness, worry, tension and dread); Depression (feelings of depression, sadness, unhappiness, negative self-image and discouragement); Mental Confusion (feelings of stunning, depression, uncertainty, and poor attention control and emotions); Anger (feelings of anger, anger, hostility, dislike, moodiness, and irritation); Fatigue (feeling of exhaustion, exhaustion, apathy, low energy level, drowsiness and tiredness) and Vigor (feeling of energy, disposition, animation and alertness).

It should be noted that the Vigor dimension is the only one that represents a positive humoral aspect related to excitation sensations and physical energy. The other dimensions represent the negative aspects of humor. ${ }^{25}$

For each of the four items, which make up each question of the six dimensions of the POMS, values ranging from "zero"to "four" were assigned, where, except for the Vigor factor, for which "zero" represents the least intense feeling or negative and "four"the feeling more intense or positive.

The calculation of the final inventory score was performed as recommended by Cruz and Mota, ${ }^{26}$ so that the final score was obtained by summing the five items of the negative dimensions (tension, depression, mental confusion, anger and fatigue), subtracting from this result, the points obtained in the positive dimension (Vigor), adding to the final result 100 points.

For the purpose of statistical calculations, the inventory was applied at two different times: 10 minutes before the walking session (pre-test situation) and shortly thereafter (post-test situation).

\section{Walking Intensity Evaluation}

The subjective perception of effort (PSE) was classified with the help of the Borg Scale. ${ }^{6-20,26}$

The walk was performed outdoors, in the same route usually used, and had a total duration of 30 minutes. During exercise, subjects should report PSE between 12 and 16 points, equivalent to $60 \%$ of the reserve heart rate, ${ }^{27}$ in order to characterize the effort intensity between mild to moderate. ${ }^{28}$

\section{Statistical treatment}

After verifying the normal distribution of the data, using the Shapiro-Wilks test, as proposed by Cruz and Mota ${ }^{26}$ the arithmetic mean, standard deviation ( \pm SD), and amplitude were used to organize and present the results. The comparison between the means of punctuation in the pre- and post-test situations was performed using Student's t-test for dependent samples or its non-parametric correlate, the Wilcoxon Signed Rankt test.
All statistical calculations were analyzed by adopting a level of significance of $\mathrm{p}<0.05$, with SPSS version 18.0 statistical software for Windows (SPSS Inc. Chicago, IL).

\section{RESULTS}

Among the 46 participants in the sample (37 women and six men) aged 60 to 78 years ( $68.6 \pm 4.5$ years), the following characteristics were reported: $49 \%$ were married, 39\% were widowers and, 12\% were single; $59 \%$ declared monthly income higher than $\mathrm{R} \$ 1,020.00$ (one thousand and twenty reais); $3 \%$ reported excellent health, $14 \%$ very good, $38 \%$ good, $33 \%$ bad and very poor; $20 \%$ reported severe pain and $18 \%$ were very severe in the last four weeks; $70 \%$ lived in multigenerational housing; 59\% declared to be hypertensive, 12\% diabetic and 15\% mild depressive.

When asked about the quality of life of the family, the majority responded between good (38\%) and very good (30\%). The presentation and comparison between the results of the $\mathrm{EH}$ : pre and post-test of each the dimensions of the POMS can be observed in Table 1.

As can be seen in the Table 1, after the intervention, the six dimensions of POMS presented relative and positive changes. However, only for Stamina and Confusion, the differences were statistically significant, while for Fatigue was borderline $(p=0,049)$

Table 1. Comparisons between the results of the mood test in both situations: before (pre) and after (post-test) the walking session $(n=43)$.

\begin{tabular}{|c|c|c|c|c|c|c|}
\hline \multirow{2}{*}{$\begin{array}{c}\text { Dimensions } \\
\text { of Mood State }\end{array}$} & \multicolumn{2}{|c|}{ Pré-test } & \multicolumn{2}{|c|}{ Pós-test } & \multirow{2}{*}{$\Delta \operatorname{dif}(\%)$} & \multirow{2}{*}{\begin{tabular}{|c|}
$P$ \\
Value
\end{tabular}} \\
\hline & $M \pm S D$ & Amplitude & $M \pm S D$ & Amplitude & & \\
\hline Tension & $1,1 \pm 0,0$ & $0-5$ & $0,7 \pm 0,0$ & $0-6$ & 27 & 0,308 \\
\hline Fatigue & $1,0 \pm 1,4$ & $0-5$ & $0,7 \pm 0,7$ & $0-6$ & 33 & $0,049^{*}$ \\
\hline Depression & $0,5 \pm 0,0$ & $0-5$ & $0,3 \pm 0,7$ & $0-5$ & 35 & 0,359 \\
\hline Vigor & $9,9 \pm 4,9$ & $4-16$ & $12,4 \pm 3,5$ & $6-16$ & 16 & $0,000^{* *}$ \\
\hline Confusion & $0,7 \pm 0,0$ & $0-4$ & $0,3 \pm 0,0$ & $0-3$ & 53 & $0,026^{*}$ \\
\hline Anger & $0,4 \pm 1,4$ & $0-3$ & $0,2 \pm 0,0$ & $0-2$ & 56 & 0,090 \\
\hline
\end{tabular}

\section{DISCUSSION}

The results of the present study demonstrated that a 30-minute walking session, the minimum amount of time recommended by most international guidelines for achieving physical health benefits, ${ }^{1}$ performed with moderate intensity was able to promote positive and significant changes in the Mood State of physically active seniors.

Regarding the importance of the observed responses, although the Fatigue dimension presented borderline results $(p=0.049)$, Vigor $(p=0.000)$ and Confusion showing important ( $p=0.026$ and $p=0.000$, respectivily). It is important to consider that, although not statistically significant, relatives differences were observed in the other three dimensions, ranging from $50 \%$ to $64 \%$ (Rage $=50 \%$, Tension $=64 \%$ and Depression $=60 \%$ ). In this way, it is possible to defend the hypothesis that, in daily situations, the observed percentages of change can represent real positive changes in MS.

Although the results observed in this study are similar to those found in other studies, such as those by Cisneiros30 and Ellis, Randall \& Punett ${ }^{17}$ it is important to consider that comparisons between studies are impaired due to the differences between the samples and, especially due to the durations of the interventions. In the mentioned studies, times between 45 and 60 minutes were used.

On the other hand, the majority of studies carried out with the elderly, aiming to verify changes in MS, used older and sedentary subjects with low levels of physical fitness, functional limitations and/or clinical diagnosis of mental disease.

In the study by Ellis, Randall \& Punett, ${ }^{17}$ for example, the authors observed the effects of a single walking session performed with moderate 
intensity. However, the duration of the intervention was longer (45 min), the participants had a large age range (19 to 70 years), besides the fact that the majority of the subjects were diagnosed with anxiety (52.5\%), depression 32.3\%), schizophrenia (6.1\%), bipolarity (4.6\%) and alcoholism (3.1\%).

In that study the authors did not observe a significant difference in the Fatigue dimension, however, they defended the hypothesis that the result may have been due to misinterpretation of the participants. In other words, in according to the author, there was the possibility that the subjects confused mental fatigue with physical fatigue. In the present study, the questionnaires were applied as an interview, which possibly facilitated the understanding of the questions raised about the evaluation of MD.

Cisneiros $^{29}$ investigated MS in a sample of 11 people (nine women and three men), aged between 64 and 95 years; The author verified statistically significant changes in all dimensions of POMS. However, it is important to consider that, in addition to being physically inactive, the sampled subjects were older with (mean age of 78 years), which may have favored proportionally higher gains due to the "window of adaptation" phenomena. The high relative difference observed in the vigor dimension (125\%) in the present study may be related to the fact that the subjects are physically active. Therefore, the fact that walking is a habitual and well-known activity may require lower levels of physical exertion, discomfort and fatigue, besides favoring the meeting of people and motivation.

The observed results allow to conclude that a 30-minute walk may be an effective way of promoting positive mood changes in apparently healthy and physically active elderly individuals. Thus, walking can be used as a non-drug strategy for the treatment of depression. In addition, walking is a natural and habitual activity, making the activity an interesting option for people with problems adhering to the usual practice of exercises, as is common in people diagnosed with some uncles of mental illnesses.

All authors declare no potential conflict of interest related to this article

AUTHORS' CONTRIBUTIONS: Each author made significant individual contributions to this manuscript: AARG (0000-0002-4222-2264)*: substantial contribution in the conception, design, analysis and interpretation of data for the work; critical review of the intellectual content of the work; revision and final approval of the version of the manuscript. WBS (00000002-1236-590X)*: substantial contribution in the conception, design, acquisition and interpretation of data for the work, besides having participated actively in the discussion of results. PBJr. (0000-0002-9148-6717)*: substantial contribution in the analysis and interpretation of data for the work, revision and final approval of the version of the manuscript. PMGP (0000-0002-7278-2385)*: critical review of its intellectual content, revision and final approval of the version of the manuscript. *ORCID (Open Researcher and Contributor ID).

\section{REFERENCES}

1. Nelson ME, Rejeski WJ, Blair SN, Duncan PW, Judge JO, King AC, et al. Physical activity and public health in older adults: recommendation from the American College of Sports Medicine and the American Heart Association. Med Sci Sports Exerc. 2007;39(8):1435-45.

2. Janyacharoen T, Laophosri M, Kanpittaya J, Auvichayapat P, Sawanyawisuth K. Physical performance in recently aged adults after 6 weeks traditional Thai dance: a randomized controlled trial. Clin Interv Aging. 2013;8:855-9.

3. Murrock CJ, Graor CH. The Effects of Dance on Depression, Physical Function, and Disability in Underserved Adults. J Aging Phys Act. 2014;22(3):380-5.

4. Adler PA, Roberts BL. The use of Tai Chi to improve health in older adults. Orthop Nurs. 2006;25(2):122-6.

5. Farinatti PT, Geraldes AA, Bottaro MF, Lima MV, Albuquerque RB, Fleck SJ. Effects of Different Resistance Training Frequencies on the Muscle Strength and Functional Performance of Active Women Older Than 60 Years. J Strength Cond Res. 2013;27(8):2225-34

6. Hatta A, Nishihira Y, HigashiuraT. Effects of a single bout of walking on psychophysiologic responses and executive function in elderly adults: a pilot study. Clin Interv Aging. 2013;8:945-52.

7. McDermott MM, Liu K, Guralnik JM, Criqui MH, Spring B, Tian L, et al. Home-based walking exercise intervention in peripheral artery disease: a randomized clinical trial. JAMA. 2013;310(1):57-65

8. Parmenter BJ, Raymond J, Dinnen P, Singh MA. A systematic review of randomized controlled trials: Walking versus alternative exercise prescription as treatment for intermittent claudication. Atherosclerosis. 2011;218(1):1-12

9. Mangialasche F, Kkivipelto M, Solomon A, Fratiglioni L. Dementia prevention: current epidemiological evidence and future perspective. Alzheimers Res Ther. 2012;4(1):6.

10. Bridle C, Spanjers K, Patel S, Atherton NM, Lamb SE. Effect of exercise on depression severity in older people: systematic review and meta-analysis of randomised controlled trials. Br J Psychiatry. 2012;201(3):180-5.

11. Archer T, Josefsson T, Linwall M. Effects of physical exercise on depressive symptoms and biomarkers in depression. CNS Neurol Disord Drug Targets. 2014;13(10):1630-53.

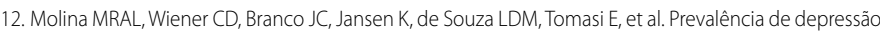
em usuários de unidades de atenção primária. Rev Psiquiatr Clín. 2012;(39)6:194-7.

13. Garcia LAA, Milani J, Celeste LFN, Chagas MO, Caixeta TP, Santos AS. Inactividad física y depresión en los ancianos en Brasil: una revisión sistemática. REFACS. 2017;5(1):66-74.

14. Sandra-Gutierrez JM, Asensio-Moreno I, Vargas-Aragón ML. Characteristics and factors associated with depression in the elderly in Spain from a gender perspective. Actas Esp Psiquiatr. 2017;45(5):185-200.

15. Andrade LH, Andreoni L, Silveira CM, Silva AC, Nishimura R, James AC, et al. Mental disorders in megacities: findings from the São Paulo Megacity Mental Health Survey, Brazil. PLoS ONE. 2012;7(2):e31879

16. Fleck MPA, Lima AFBS, Louzada S, Schestasky G, Henriques A, Borges VR, et al. Associação entre sintomas depressivos e funcionamento social em cuidados primários à saúde. Rev Saude Publica. 2002;36(4):431-8

17. Ellis NJ, Randall JA, Punett G. The Effects of a Single Bout of Exercise on Mood and Self-Esteem in Clinically Diagnosed Mental Health Patients. Open Journal of Medical Psychology. 2013;2:81-5.

18. Lampinen P, Heikkinen RL, Ruoppila I. Changes in intensity of physical exercise as predictors of depressive symptoms among older adults: an eight-year follow-up. Prev Med. 2000;30(5):371-80.

19. Werneck FZ, Navarro CA. Nível de Atividade Física e Estado de Humor em Adolescentes. Psic: Teor Pesq. 2011;27(2):189-93

20. Powers MB, Asmundson GJG, Smits JAJ. Exercise for mood and anxiety disorders: The state-of-the science. Cogn Behav Ther. 2015;44(4):237-9.

21.Zschucke E, Gaudlitz K, Ströhle A. Exercise and Physical Activity in Mental Disorders: Clinical and Experimental Evidence. J Prev Med Public Health. 2013;46(Suppl1):S12-21.

22. Ahtiainen JP, Pakarinen A, Alen M, Kraemer WJ, Hakkinen K. Muscle hypertrophy, hormonal adaptation and strength development during strength training in strength-trained and untrained men. Eur J App Physiol. 2003;89(6):555-63.

23. McNair DM, Lorr M, Droppleman LF. Manual for the profile of mood states. San Diego, CA: Educational and Industrial Testing Services; 1971

24. Rohlfs ICPM. A Escala de Humor de Brunel (Brums): instrumento para detecção precoce da síndrome do excesso de treinamento. Rev Bra Med Esporte. 2008;14(3):176-81.

25. Werneck FZ, Navarro CA. Nível de Atividade Física e Estado de Humor em Adolescentes. Psic: Teor Pesq. 2011;27(2):189-93

26. Cruz J, Mota MP. Adaptação e características psicométricas do "POMS-Profile of Mood States" e do "STAI-State-Trait Anxiety Inventory" In: Gonçalves M, Ribeiro I, Araújo S, Machado C, Almeida L, Simões M (eds.). Avaliação Psicológica: Formas e Contextos. Braga: Universidade do Minho; 1997.

27. Mazzeo R, Cavanag P, Evans W, Fiatarone M, Hagberg J, Mc Auley E, et al. Exercise and physical activity for older adults. Med Sci Sports Exerc. 1998;30(6):992-1008.

28. Mattos M, Farinatti P. Influência do treinamento aeróbio com intensidade e volume reduzidos na autonomia e aptidão físico-funcional de mulheres idosas. Rev Port Ciên Desp. 2007;7(1):100-8.

29. Cisneiros PMSP. Influência de um programa de exercício físico sobre a capacidade física funcional e os estados de humor numa população idosa. Monografia de Licenciatura em Ciências do Desporto e Educação Física da Universidade de Coimbra, 2005 [accessed on 2017 Out. 15]; Available at: https:// estudogeral.sib.uc.pt/handle/10316/15525. 